\title{
Seedling Growth of Two Honey Mesquite Varieties Under $\mathrm{CO}_{2}$ Enrichment
}

\author{
Justin D. Derner, ${ }^{1}$ Charles R. Tischler, ${ }^{2}$ H. Wayne Polley, ${ }^{3}$ \\ and Hyrum B. Johnson ${ }^{4}$
}

\author{
Authors are ${ }^{1}$ Rangeland Scientist, USDA-ARS, High Plains Grasslands Research Station, \\ 8408 Hildreth Road, Cheyenne, WY 82009; and ${ }^{2}$ Plant Physiologist, ${ }^{3}$ Research Leader, and \\ ${ }^{4}$ Ecologist, USDA-ARS, Grassland, Soil \& Water Laboratory, \\ 808 East Blackland Road, Temple, TX 76502.
}

\begin{abstract}
Seedlings of 2 varieties of honey mesquite (Prosopis glandulosa var. glandulosa and P. glandulosa var. torreyana) were exposed to 2 concentrations of atmospheric carbon dioxide $\left(\mathrm{CO}_{2}\right)\left(368\right.$ and $\left.704 \mu \mathrm{mol} \cdot \mathrm{mol}^{-1}\right)$ in environmentally controlled glasshouses under near-optimal temperature and soil water conditions to determine if $\mathrm{CO}_{2}$ enrichment alters above- and belowground growth responses. $\mathrm{CO}_{2}$ enrichment substantially enhanced both above- and belowground growth variables of both varieties for all harvest dates $(8,16$, and 24 days postemergence). This growth enhancement was greater for aboveground variables $(21 \%-$ $35 \%)$ at the first harvest, greater for belowground variables $(36 \%-40 \%)$ at the second harvest, and similar for both above$(13 \%-68 \%)$ and belowground $(10 \%-40 \%)$ variables at the last harvest. Differences in temporal growth enhancement associated with $\mathrm{CO}_{2}$ enrichment suggest changing carbon allocation priorities, with initial carbon investment allocated primarily aboveground to develop photosynthetic machinery, and later carbon allocations predominately directed toward increased investment in roots. The absence of significant $\mathrm{CO}_{2} \times$ variety interactions at any harvest date provides evidence that $\mathrm{CO}_{2}$ enrichment did not exaggerate growth responses between the 2 varieties. These results suggest that varietal differences in rooting and other characteristics did not modify the size advantage of the glandulosa over the torreyana variety, as the absolute differences in sizes did not change as a function of $\mathrm{CO}_{2}$ treatment. Although $\mathrm{CO}_{2}$ enrichment did not exaggerate growth differences between varieties in this species, it is evident that honey mesquite seedlings possess the capacity to respond markedly to $\mathrm{CO}_{2}$ enrichment. The greater root depth of honey mesquite seedlings exposed to $\mathrm{CO}_{2}$ enrichment confers a competitive advantage to mesquite seedlings over grass seedlings, assuming that $\mathrm{C}_{3}$ and $\mathrm{C}_{4}$ grass seedlings will not respond as vigorously to $\mathrm{CO}_{2}$ enrichment. As such, this species should continue to aggressively encroach into grasslands in future $\mathrm{CO}_{2}$-enriched environments.
\end{abstract}

\section{Resumen}

Plántulas de dos variedades de "Mesquite" (Prosopis glandulosa var. glandulosa y P. glandulosa var. torreyana) fueron expuestas a dos concentraciones de $\mathrm{CO}_{2}\left(368\right.$ y $\left.704 \mu \mathrm{mol} \cdot \mathrm{mol}^{-1}\right)$ en invernaderos con ambiente controlado bajo condiciones de temperatura y humedad en suelo cercanas al óptimo a fin de determinar si el enriquecimiento de $\mathrm{CO}_{2}$ altera la respuesta del crecimiento aéreo y radicular. El enriquecimiento de $\mathrm{CO}_{2}$ mejoró sustancialmente las variables del crecimiento tanto aéreo como radicular en ambas variedades en todas las fechas de cosecha $(8,16$, y 24 días a la postemergencia). El estímulo al crecimiento fue mayor para variables de crecimiento aéreo $(21 \%-35 \%)$ en el primer corte, mayor para variables de crecimiento radicular $(36 \%-$ $40 \%$ ) en el segundo corte y similar para ambos aéreo $(13 \%-68 \%)$ y radicular $(10 \%-40 \%)$ en el último corte. Las diferencias en la mejoría temporal del crecimiento asociadas al enriquecimiento de $\mathrm{CO}_{2}$ sugieren un cambio en las prioridades de ubicación del carbón, con inversiones iniciales de carbón asignadas principalmente al a la parte aérea a fin de desarrollar la maquinaria fotosintética y translocación posterior de carbón para el crecimiento de raíces. La ausencia de interacciones significativas de $\mathrm{CO}_{2}$ $\mathrm{X}$ variedad en cualquier fecha de cosecha provee evidencia de que el enriquecimiento de $\mathrm{CO}_{2}$ no estimula exageradamente la respuesta al crecimiento entre las dos variedades. Los resultados sugieren que las diferencias varietales en raíces y otras características no modifican la ventaja del tamaño de la glandulosa sobre la torreyana, las diferencias absolutas en tamaño no cambian en función de los tratamientos de $\mathrm{CO}_{2}$. Aunque el enriquecimiento de $\mathrm{CO}_{2}$ no magnificó las diferencia de crecimiento entre variedades de esta especie, es evidente que las plántulas de "Mesquite" poseen la capacidad de responder marcadamente al enriquecimiento de $\mathrm{CO}_{2}$. La mayor profundidad de raíces de plántulas de mesquite expuestas al enriquecimiento de $\mathrm{CO}_{2}$ le confiere una ventaja competitiva sobre plántulas de zacates, asumiendo que las plántulas de zacates $\mathrm{C}_{3} \mathrm{y}_{4}$, no responderan $\tan$ vigorosamente al enriquecimiento de $\mathrm{CO}_{2}$. Por lo tanto, en el futuro, esta especie continuará expandiéndose agresivamente hacia los pastizales en ambientes enriquecidos con $\mathrm{CO}_{2}$.

Key Words: atmospheric carbon dioxide, leguminous shrub, root growth, shrub encroachment 


\section{INTRODUCTION}

Honey mesquite (Prosopis glandulosa Torr.) is a leguminous shrub that has displaced native herbaceous vegetation in arid and semiarid rangeland ecosystems of the southwestern United States (Archer 1989, 1990, 1995; Van Auken 2000; Ansley et al. 2001). Two varieties of honey mesquite occupy distinct habitats in this region. Prosopis glandulosa var. glandulosa occurs in mesic environments of west-central and central Texas (Burkhart 1976) as large, single-stem trees, whereas Prosopis glandulosa var. torreyana occurs in xeric environments of west Texas and southern New Mexico (Hilu et al. 1982) as short, multi-stem shrubs. Pennington et al. (1999) found that under well-watered conditions the carbon isotope composition of leaves, a surrogate for leaf water-use efficiency, differed between seedlings of honey mesquite from xeric and mesic habitats, strongly suggesting a genetic difference between types. Additionally, random amplified polymorphic DNA (RAPD) marker results classified honey mesquite trees along the southern portion of the New Mexico-Texas border as the variety torreyana and trees from central Texas as the variety glandulosa (Pennington and Tischler, personal communication, 2004).

Bond and Midgley (2000) suggested that invasion by woody plants and subsequent increase in density of these species in grass-dominated ecosystems may be attributable to a significant positive effect of atmospheric carbon dioxide $\left(\mathrm{CO}_{2}\right)$ enrichment on growth of woody plant species. The relative responsiveness of these 2 honey mesquite varieties to $\mathrm{CO}_{2}$ enrichment may indicate which will more aggressively encroach into rangelands in the future. Previous investigations have identified speciesspecific (e.g., Joel et al. 2001; Goverde et al. 2002) and genotype-specific (e.g., Roumet et al. 2002) responses of plants to $\mathrm{CO}_{2}$ enrichment. Dissimilar growth responses to $\mathrm{CO}_{2}$ for these 2 honey mesquite varieties may be manifested in differential rates of shrub encroachment in arid and more mesic rangelands (Polley 1997; Polley et al. 1997).

Our objective in this investigation was to determine if $\mathrm{CO}_{2}$ enrichment exaggerates variation in above- and belowground growth responses between 2 honey mesquite varieties. Because plants from mesic environments generally grow faster than those from arid environments (Chapin 1980; Lambers and Poorter 1992) and $\mathrm{CO}_{2}$ enrichment usually increases relative growth rate (RGR)(Poorter 1993) and biomass (Bunce 1997) of species that grow rapidly, we tested the null hypothesis that $\mathrm{CO}_{2}$ enrichment does not preferentially increase growth of honey mesquite from mesic (var. glandulosa) compared to xeric (var. torreyana) environments. We assessed above- and belowground growth responses by growing seedlings of honey mesquite in environmentally-controlled glasshouses at nearoptimal temperature and soil water conditions. Because the first weeks of growth are most critical to the establishment of honey mesquite (Polley et al. 2002a), we evaluated growth responses during this time period. In addition, $\mathrm{CO}_{2}$ effects on plant growth may be transient (Poorter 1993; Centritto et al. 1999), disappearing after seedlings are just a few weeks old; therefore, we conducted multiple harvests during the first weeks of growth to discern the time-course of $\mathrm{CO}_{2}$ responses through measurements of RGR (Polley et al. 2002b). Understanding the basic ecological responses to $\mathrm{CO}_{2}$ enrichment of varieties of honey mesquite seedlings from contrasting environments may assist in assessing the invasiveness of this noxious shrub in rangelands.

\section{MATERIALS AND METHODS}

Seeds were collected in late July 2000 from 3 individual trees (genotypes) from each of 2 sites: the Temple, Texas vicinity $(87.9 \mathrm{~cm}$ mean annual precipitation [MAP]) and near the Texas-New Mexico border off Interstate 10 (24.7 cm MAP), which is about $1050 \mathrm{~km}$ to the west of the Temple site. Caution was taken to ensure that these trees were at least $2 \mathrm{~km}$ from any major road. As noted previously, RAPD marker results of trees in the vicinity of our collection sites (but not our trees specifically) classified honey mesquite trees near the Texas-New Mexcio border as the variety torreyana and trees from central Texas as the variety glandulosa (Pennington and Tischler, personal communication, 2004).

To prevent confounding influences of seed mass on initial seedling development (Villar et al. 1998), seeds of each genotype were weighed prior to planting to ensure similar seed mass within a genotype. On 14 June 2001, 2 seeds of each genotype were planted in each of 36 pots (each pot measuring $0.05 \mathrm{~m}$ in diameter $\times 1.60 \mathrm{~m}$ deep), for a total of 216 pots. Pots were constructed from polyvinyl chloride pipe cut longitudinally into 2 pieces of equal size to facilitate recovery of intact root systems. The 2 halves of each pot were taped together and secured at the base with a perforated cap. Pots were filled with a sandy loam soil (Alfisol, Udic Paleustalfs; Huckabee et al. 1977) with the following properties: $\mathrm{pH}=7.1$, organic carbon content $=0.57 \%, 76.2 \%$ sand, $16.2 \%$ silt, $7.6 \%$ clay, field capacity $=18 \%$ on a volumetric basis. Soil in the pots was wetted to drip prior to planting by adding halfstrength Hoagland's nutrient solution (Hoagland and Arnon, 1950). Following planting, pots with each genotype were randomly assigned to 1 of 4 glasshouse bays. Two bays were maintained at ambient $\mathrm{CO}_{2}$ and 2 at elevated $\mathrm{CO}_{2}$, with 9 pots per genotype in each bay $(2$ varieties $\times 3$ genotypes per $\begin{array}{llll}\text { variety } & \times 2 & \mathrm{CO}_{2} & \text { concentrations }\end{array} \times 2$ glasshouse bays $\times 9$ pots/genotype/bay $=216$ pots). Full-strength Hoagland's solution was added daily to each pot to maintain soil water content near field capacity. Seedlings were thinned to 1 per pot following emergence.

The $\mathrm{CO}_{2}$ concentration of air in each of 4 glasshouse bays was measured at 4-minute intervals with a Li-Cor Model LI6262 infrared gas analyzer (Li-Cor, Inc., Lincoln, NE). The $\mathrm{CO}_{2}$ readings were corrected for atmospheric pressure measured with a Druck Model DPI 260 pressure indicator (Druck, Inc., New Fairfield, CT). The infrared analyzer was calibrated daily against $4 \mathrm{CO}_{2}$ gas standards and weekly against a Li-Cor LI-610 dewpoint generator (Li-Cor). Air temperature, manually set at $30^{\circ} \mathrm{C}$ for both day and night, was measured in the center of each bay with fine-wire $(25-\mu \mathrm{m}$ diameter $)$ thermocouples. Pure $\mathrm{CO}_{2}$ gas was injected into appropriate bays as required to maintain the elevated $\mathrm{CO}_{2}$ concentration. The $\mathrm{CO}_{2}$ concentration of air in the ambient and elevated $\mathrm{CO}_{2}$ treatments averaged 368 and $704 \mu \mathrm{mol} \cdot \mathrm{mol}^{-1}$, respectively. Photosynthetic photon flux density (PPFD) was measured on the glasshouse roof with a quantum sensor (LI-190SB; Li-Cor) and within the glasshouse 
Table 1. Mean ( $\pm 1 \mathrm{SE}$ ) above- and belowground responses at 8 days postemergence of 2 varieties of mesquite seedlings exposed to ambient and elevated $\mathrm{CO}_{2}$ concentrations (368 and $704 \mu \mathrm{mol} \cdot \mathrm{mol}^{-1}$, respectively).

\begin{tabular}{|c|c|c|c|c|c|}
\hline \multirow[b]{2}{*}{ Variable } & \multicolumn{2}{|c|}{$\mathrm{CO}_{2}$} & \multirow[b]{2}{*}{$\%$ Increase $^{2}$} & \multicolumn{2}{|c|}{ Variety } \\
\hline & Ambient & Elevated & & torreyana & glandulosa \\
\hline \multicolumn{6}{|l|}{ Aboveground } \\
\hline Cotyledon area $\left(\mathrm{cm}^{2}\right)$ & $3.06(0.12)$ & $3.06(0.12)$ & 0 & $2.89(0.12)$ & $3.23(0.12)^{1}$ \\
\hline Cotyledon mass (g) & $0.017(0.001)$ & $0.023(0.001)^{1}$ & 35 & $0.019(0.001)$ & $0.021(0.001)$ \\
\hline Leaf pair 1 area $\left(\mathrm{cm}^{2}\right)$ & $3.15(0.18)$ & $3.39(0.18)$ & 8 & $3.16(0.18)$ & $3.38(0.18)$ \\
\hline Leaf pair 1 mass (g) & $0.010(0.001)$ & $0.013(0.001)$ & 30 & $0.011(0.001)$ & $0.012(0.001)$ \\
\hline Other leaf mass (g) & $0.014(0.001)$ & $0.017(0.001)$ & 21 & $0.015(0.001)$ & $0.016(0.001)$ \\
\hline Stem mass $(\mathrm{g})$ & $0.009(0.001)$ & $0.012(0.001)$ & 33 & $0.009(0.001)$ & $0.012(0.001)$ \\
\hline Total leaf mass $(\mathrm{g})$ & $0.040(0.002)$ & $0.053(0.002)^{1}$ & 33 & $0.044(0.002)$ & $0.049(0.002)$ \\
\hline Aboveground mass $(\mathrm{g})$ & $0.049(0.003)$ & $0.065(0.003)^{1}$ & 33 & $0.053(0.003)$ & $0.061(0.003)^{1}$ \\
\hline \multicolumn{6}{|l|}{ Belowground } \\
\hline Root depth (cm) & $83(3)$ & $94(3)^{1}$ & 13 & $86(3)$ & $90(3)$ \\
\hline Root length (cm) & $139.9(10.0)$ & $150.9(9.4)$ & 8 & $135.5(10.0)$ & $155.4(9.4)$ \\
\hline Root surface area $\left(\mathrm{cm}^{2}\right)$ & $23.2(1.2)$ & $25.6(1.1)$ & 10 & $22.8(1.2)$ & $26.0(1.1)^{1}$ \\
\hline Root volume $\left(\mathrm{m}^{3}\right)$ & $0.31(0.02)$ & $0.35(0.01)^{1}$ & 13 & $0.30(0.02)$ & $0.35(0.01)^{1}$ \\
\hline Root mass (g) & $0.017(0.001)$ & $0.021(0.001)^{1}$ & 24 & $0.016(0.001)$ & $0.022(0.001)^{1}$ \\
\hline \multicolumn{6}{|l|}{ Whole plant } \\
\hline Total plant mass $(\mathrm{g})$ & $0.064(0.004)$ & $0.086(0.004)^{1}$ & 34 & $0.068(0.004)$ & $0.083(0.004)^{1}$ \\
\hline
\end{tabular}

${ }^{1}$ Significant at the 0.05 level between ambient and elevated $\mathrm{CO}_{2}$ means across varieties, and between variety means across [ $\left[\mathrm{CO}_{2}\right]$.

${ }^{2}$ Increase $(\%)$ of elevated $\left[\mathrm{CO}_{2}\right]$ over ambient $\left[\mathrm{CO}_{2}\right]$.

bays with 1-m-long line quantum sensors (LI-191SA; Li-Cor) mounted about plant height. On average, the daily integral of PPFD inside the glasshouse bays was $73 \%$ of that measured above the glasshouse.

Seedlings were harvested at 8,16 , and 24 days postemergence from each of the glasshouse bays. Aboveground biomass was separated into stem and leaf components with the area of each leaf blade measured using a LI-3000A portable leaf area meter (Li-Cor). Soil was manually washed from roots and the depth of deepest root penetration recorded. Roots were digitally scanned at high resolution (600 dpi) using the WinRHIZO software (version 4.1c; Regent Instruments, Inc., Quebec, Canada) and a Hewlett Packard ScanJet 6100C scanner to determine root length, surface area, and root volume. Roots were not stained prior to analyses, which results in underestimations (Bouma et al. 2000), but these were minimized by using the WinRHIZO automatic threshold (i.e., Lagarde's method) for pale roots with greater sensitivity. Aboveground tissues and roots were dried at $60^{\circ} \mathrm{C}$ for 72 hours prior to weighing. RGRs were calculated for each genotype for the 0-8-, 8-16-, 16-24-, and 0-24-day intervals using observed total biomass (aboveground + belowground) for the latter harvest date and the genotype mean for the previous harvest date. Average seed mass was used in calculations involving day 0 .

Data were analyzed by harvest date using a split-split plot design with $\mathrm{CO}_{2}$ as the split plot and variety as the split-split plot in a balanced design (SAS Institute Inc. 1997). The 0.05 level of probability was used for all analyses. Single degree of freedom contrasts were used to compare the 3 genotypes within each variety. When needed to normalize residuals, data were logarithmically transformed before analysis; means and standard errors are reported after back-transforming.

\section{RESULTS}

\section{Day 8 Harvest}

$\mathrm{CO}_{2}$ enrichment increased mass of cotyledons, leaves, and total aboveground plant material by $33 \%-35 \%$; aboveground plant mass was $15 \%$ greater for seedlings of the glandulosa than for the torreyana variety (Table 1). $\mathrm{CO}_{2}$ enrichment enhanced root depth, root volume, and root mass by $13 \%-24 \%$; root surface area, root volume, and root mass were $14 \%-38 \%$ greater for the glandulosa than for the torreyana variety. Aboveground responses generally displayed greater increases $(21 \%-35 \%)$ with $\mathrm{CO}_{2}$ enrichment than did belowground responses $(8 \%-$ $24 \%$ ). Total plant mass was $34 \%$ greater with $\mathrm{CO}_{2}$ enrichment

Table 2. Mean ( $\pm 1 \mathrm{SE})$ relative growth rates $\left(\mathrm{RGR}, \mathrm{g} \cdot \mathrm{g}^{-1} \cdot\right.$ day $\left.^{-1}\right)$ of 2 varieties of mesquite seedlings exposed to ambient and elevated $\mathrm{CO}_{2}$ concentrations (368 and $704 \mu \mathrm{mol} \cdot \mathrm{mol}^{-1}$, respectively).

\begin{tabular}{lccccc}
\hline \multirow{2}{*}{$\begin{array}{l}\text { Growth } \\
\text { Interval }\end{array}$} & \multicolumn{2}{c}{$\mathrm{CO}_{2}$} & \multirow{2}{*}{$\%$} & \multicolumn{2}{c}{ Variety } \\
\cline { 2 - 3 } \cline { 5 - 7 } & Ambient & Elevated & Increase & torreyana & glandulosa \\
\hline 0-8 days & $0.049(0.006)$ & $0.082(0.006)^{1}$ & 67 & $0.057(0.007)$ & $0.075(0.006)^{1}$ \\
8-16 days & $0.121(0.005)$ & $0.148(0.005)^{1}$ & 22 & $0.132(0.007)$ & $0.138(0.005)$ \\
16-24 days & $0.080(0.008)$ & $0.129(0.008)^{1}$ & 61 & $0.104(0.008)$ & $0.107(0.011)$ \\
0-24 days & $0.095(0.003)$ & $0.112(0.003)^{1}$ & 18 & $0.102(0.004)$ & $0.105(0.003)$ \\
\hline
\end{tabular}

${ }^{1}$ Significant at the 0.05 level between ambient and elevated $\mathrm{CO}_{2}$ means across varieties, and between variety means across $\left[\mathrm{CO}_{2}\right]$

${ }^{2}$ Increase (\%) of elevated $\left[\mathrm{CO}_{2}\right]$ over ambient $\left[\mathrm{CO}_{2}\right]$. 


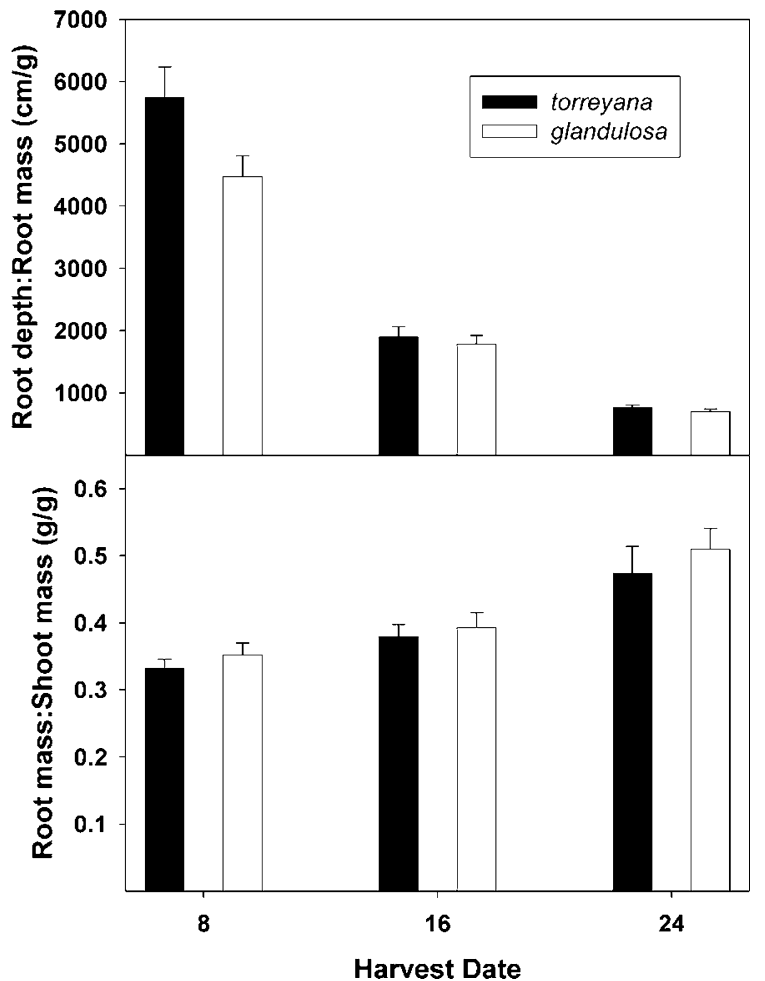

Figure 1. Mean ( $\pm 1 \mathrm{SE}$ ) root-depth to root-mass ratios (upper panel) and root-mass to shoot-mass ratios (lower panel) at 8, 16, and 24 days postemergence of 2 varieties of mesquite seedlings averaged over ambient and elevated $\mathrm{CO}_{2}$ concentrations.

and $22 \%$ greater for glandulosa than for torreyana seedlings. Concurrent with this finding, RGR (Days 0-8) was 67\% greater with $\mathrm{CO}_{2}$ enrichment and $32 \%$ greater in glandulosa than in torreyana seedlings (Table 2). Root-depth to root-mass ratios, averaged over $\mathrm{CO}_{2}$ treatments, were greater for torreyana than for glandulosa seedlings, but root-mass to shoot-mass ratios did not differ between varieties (Fig. 1). Significant interactions between $\mathrm{CO}_{2}$ and the 2 varieties were not observed for any variable, indicating that growth responses to $\mathrm{CO}_{2}$ enrichment were similar for seedlings of both varieties. There were no significant differences for above- or belowground growth responses among the 3 genotypes from each variety (data not shown).

\section{Day 16 Harvest}

In contrast to the Day 8 harvest, $\mathrm{CO}_{2}$ enrichment caused greater percentage increases in belowground variables $(36 \%-$ $40 \%$ ) other than root depth than in aboveground variables $(10 \%-35 \%)$ (Table 3$). \mathrm{CO}_{2}$ enrichment increased stem, total leaf, and aboveground plant mass by $23 \%-35 \%$. In general, the magnitude of increases with $\mathrm{CO}_{2}$ enrichment for aboveground variables was less than those observed for the Day 8 harvest. Aboveground plant mass was $12 \%$ greater for glandulosa than for torreyana seedlings. $\mathrm{CO}_{2}$ enrichment enhanced root length, root surface area, root volume, and root mass by $36 \%-40 \%$. The magnitude of $\mathrm{CO}_{2}$-induced increases for root variables was greater at the Day 16 harvest than at the Day 8 harvest. Rooting depth and root mass were $14 \%-20 \%$ greater for the glandulosa than for the torreyana variety. Total plant mass increased by $27 \%$ with $\mathrm{CO}_{2}$ enrichment and was $14 \%$ greater in glandulosa than in torreyana seedlings. RGR (Days 8-16) was $22 \%$ greater with $\mathrm{CO}_{2}$ enrichment, but did not differ between varieties (Table 2). Root-depth to root-mass and rootmass to shoot-mass ratios, averaged over $\mathrm{CO}_{2}$ treatments, did not differ between varieties, but were lower and higher, respectively, than in the Day 8 harvest (Fig. 1). Consistent with the Day 8 harvest, significant interactions between $\mathrm{CO}_{2}$ and the 2 varieties were not observed for any variable, and differences were not observed for any variable among the 3 genotypes from each variety (data not shown).

\section{Day 24 Harvest}

In contrast to the 2 previous harvests, percentage increases with $\mathrm{CO}_{2}$ enrichment were similar for both aboveground $(13 \%-$ $68 \%)$ and belowground $(10 \%-40 \%)$ variables, and $\mathrm{CO}_{2}$ enrichment increased all variables (Table 4). In general, the magnitude of increases with $\mathrm{CO}_{2}$ enrichment was greater for aboveground variables, and similar for belowground variables, compared to the Day 16 harvest. Roots of seedlings of the glandulosa variety were longer and heavier, exhibited greater surface area, and extended deeper in pots compared to roots of the torreyana variety seedlings. Total plant mass increased by $50 \%$ with $\mathrm{CO}_{2}$ enrichment, but did not differ between varieties. Concurrent with this, RGR (Days 16-24) was 61\% greater with $\mathrm{CO}_{2}$ enrichment and did not differ between varieties, whereas RGR over the entire experiment (Days 024) was $18 \%$ greater with $\mathrm{CO}_{2}$ enrichment. Consistent with Day 16 harvest, root-depth to root-mass and root-mass to shoot-mass ratios, averaged over $\mathrm{CO}_{2}$ treatments, did not differ between varieties (Fig. 1). Consistent with the 2 previous harvests, significant interactions between $\mathrm{CO}_{2}$ and the 2 varieties were not observed for any variable, and differences were not observed for any growth response among the 3 genotypes from each variety (data not shown).

\section{DISCUSSION}

Both varieties of honey mesquite responded to $\mathrm{CO}_{2}$ enrichment with enhanced growth. Seedlings of the variety glandulosa had greater biomass and a more developed root system compared to the variety torreyana at the first 2 harvests (Days 8 and 16). However, these differences were attributed to inherent variation between varieties and not to elevated $\mathrm{CO}_{2}$. The absence of significant $\mathrm{CO}_{2} \times$ variety interactions at any harvest date provides evidence that $\mathrm{CO}_{2}$ enrichment did not exaggerate differences in above- and belowground responses between varieties in this glasshouse study under near-optimal temperature and soil water conditions. Therefore, our null hypothesis that $\mathrm{CO}_{2}$ enrichment does not preferentially increase seedling growth of the honey mesquite variety from mesic environments was not rejected. These results suggest that varietal differences in rooting and other characteristics did not modify the size advantage of glandulosa over torreyana varieties, as the absolute differences in sizes did not change as a function of $\mathrm{CO}_{2}$ treatment. Our assumption that growth of plants from mesic environments is greater compared to those from arid environments was supported only over the 8 days following seedling emergence. 
Table 3. Mean ( $\pm 1 \mathrm{SE}$ ) above- and belowground responses at 16-days postemergence of 2 varieties of mesquite seedlings exposed to ambient and elevated $\mathrm{CO}_{2}$ concentrations (368 and $704 \mu \mathrm{mol} \cdot \mathrm{mol}^{-1}$, respectively).

\begin{tabular}{|c|c|c|c|c|c|}
\hline \multirow[b]{2}{*}{ Variable } & \multicolumn{2}{|c|}{$\mathrm{CO}_{2}$} & \multirow[b]{2}{*}{$\%$ Increase $^{2}$} & \multicolumn{2}{|c|}{ Variety } \\
\hline & Ambient & Elevated & & torreyana & glandulosa \\
\hline \multicolumn{6}{|l|}{ Aboveground } \\
\hline Leaf pair 1 area $\left(\mathrm{cm}^{2}\right)$ & $6.56(0.33)$ & $7.30(0.30)^{1}$ & 11 & $7.31(0.30)$ & $6.55(0.33)$ \\
\hline Leaf pair 1 mass $(\mathrm{g})$ & $0.038(0.002)$ & $0.051(0.002)^{1}$ & 34 & $0.046(0.002)$ & $0.043(0.002)$ \\
\hline Other leaf area $\left(\mathrm{cm}^{2}\right)$ & $8.12(0.82)$ & $8.99(0.75)$ & 11 & $8.10(0.75)$ & $9.01(0.82)$ \\
\hline Other leaf mass $(\mathrm{g})$ & $0.046(0.004)$ & $0.051(0.003)$ & 11 & $0.045(0.003)$ & $0.053(0.004)$ \\
\hline Stem mass $(\mathrm{g})$ & $1.046(0.039)$ & $1.412(0.057)^{1}$ & 35 & $1.403(0.056)$ & $1.048(0.048)$ \\
\hline Total leaf area $\left(\mathrm{cm}^{2}\right)$ & $17.74(1.14)$ & $19.48(1.04)$ & 10 & $18.43(1.04)$ & $18.78(1.13)$ \\
\hline Total leaf mass $(\mathrm{g})$ & $0.107(0.006)$ & $0.132(0.005)^{1}$ & 23 & $0.114(0.006)$ & $0.124(0.006)$ \\
\hline Aboveground mass (g) & $0.146(0.008)$ & $0.180(0.007)^{1}$ & 23 & $0.153(0.007)$ & $0.172(0.008)^{1}$ \\
\hline \multicolumn{6}{|l|}{ Belowground } \\
\hline Root depth (cm) & $108(5)$ & $110(5)$ & 1 & $102(5)$ & $116(5)^{1}$ \\
\hline Root length $(\mathrm{cm})$ & $179.5(12.2)$ & $251.6(11.9)^{1}$ & 40 & $215.4(11.9)$ & $215.6(12.2)$ \\
\hline Root surface area $\left(\mathrm{cm}^{2}\right)$ & $31.5(1.8)$ & $43.1(1.7)^{1}$ & 37 & $36.9(1.7)$ & $37.7(1.7)$ \\
\hline Root volume $\left(\mathrm{m}^{3}\right)$ & $0.46(0.03)$ & $0.63(0.03)^{1}$ & 37 & $0.53(0.03)$ & $0.56(0.03)$ \\
\hline Root mass (g) & $0.055(0.003)$ & $0.075(0.003)^{1}$ & 36 & $0.059(0.003)$ & $0.071(0.003)^{1}$ \\
\hline \multicolumn{6}{|l|}{ Whole plant } \\
\hline Total plant mass $(\mathrm{g})$ & $0.201(0.011)$ & $0.255(0.010)^{1}$ & 27 & $0.213(0.009)$ & $0.243(0.011)^{1}$ \\
\hline
\end{tabular}

${ }^{1}$ Significant at the 0.05 level between ambient and elevated $\mathrm{CO}_{2}$ means across varieties, and between variety means across $\left[\mathrm{CO}_{2}\right]$.

${ }^{2}$ Increase (\%) of elevated $\left[\mathrm{CO}_{2}\right]$ over ambient $\left[\mathrm{CO}_{2}\right]$.

Growth enhancement of honey mesquite with $\mathrm{CO}_{2}$ enrichment was greater for aboveground variables at the first (Day 8) harvest, greater for belowground variables at the second (Day 16) harvest, and similar for both above- and belowground variables at the last (Day 24) harvest. These differences in temporal enhancement of plant growth associated with $\mathrm{CO}_{2}$ enrichment suggest changing carbon allocation priorities. Initial carbon investment was allocated primarily aboveground to

Table 4. Mean $( \pm 1 \mathrm{SE})$ above- and belowground responses at 24-days postemergence of 2 varieties of mesquite seedlings exposed to ambient and elevated $\mathrm{CO}_{2}$ concentrations (368 and $704 \mu \mathrm{mol} \cdot \mathrm{mol}^{-1}$, respectively).

\begin{tabular}{|c|c|c|c|c|c|}
\hline \multirow[b]{2}{*}{ Variable } & \multicolumn{2}{|c|}{$\mathrm{CO}_{2}$} & \multirow[b]{2}{*}{$\%$ Increase $^{2}$} & \multicolumn{2}{|c|}{ Variety } \\
\hline & Ambient & Elevated & & torreyana & glandulosa \\
\hline \multicolumn{6}{|l|}{ Aboveground } \\
\hline Leaf pairs & $9.2(0.5)$ & $10.7(0.5)^{1}$ & 16 & $9.4(0.5)$ & $10.6(0.5)$ \\
\hline Leaf pair $2 \& 3$ area $\left(\mathrm{cm}^{2}\right)$ & $7.03(0.36)$ & $7.95(0.34)^{1}$ & 13 & $7.51(0.36)$ & $7.48(0.34)$ \\
\hline Leaf pair $2 \& 3$ mass $(\mathrm{g})$ & $0.045(0.003)$ & $0.053(0.002)^{1}$ & 18 & $0.050(0.003)$ & $0.048(0.003)$ \\
\hline Other leaf area $\left(\mathrm{cm}^{2}\right)$ & $18.93(4.10)$ & $31.83(3.83)^{1}$ & 68 & $25.77(4.10)$ & $24.99(3.83)$ \\
\hline Other leaf mass ( $\mathrm{g}$ ) & $0.103(0.021)$ & $0.170(0.020)^{1}$ & 65 & $0.139(0.022)$ & $0.135(0.021)$ \\
\hline Stem mass (g) & $0.100(0.013)$ & $0.160(0.012)^{1}$ & 60 & $0.111(0.013)$ & $0.151(0.013)^{1}$ \\
\hline Total leaf area $\left(\mathrm{cm}^{2}\right)$ & $37.04(4.41)$ & $52.87(4.21)^{1}$ & 43 & $47.80(4.60)$ & $42.11(4.01)$ \\
\hline Total leaf mass (g) & $0.213(0.23)$ & $0.311(0.023)^{1}$ & 46 & $0.278(0.024)$ & $0.246(0.021)$ \\
\hline Aboveground mass (g) & $0.314(0.033)$ & $0.480(0.032)^{1}$ & 53 & $0.397(0.034)$ & $0.397(0.031)$ \\
\hline \multicolumn{6}{|l|}{ Belowground } \\
\hline Root depth (cm) & $114(3)$ & $126(3)^{1}$ & 10 & $116(4)$ & $125(3)^{1}$ \\
\hline Root length $(\mathrm{cm})$ & $364.6(31.6)$ & $488.3(28.9)^{1}$ & 34 & $379.7(31.0)$ & $473.2(29.5)^{1}$ \\
\hline Root surface area $\left(\mathrm{cm}^{2}\right)$ & $67.8(4.9)$ & $87.8(4.5)^{1}$ & 29 & $70.9(4.8)$ & $84.7(4.6)^{1}$ \\
\hline Root volume $\left(\mathrm{m}^{3}\right)$ & $1.03(0.08)$ & $1.35(0.07)^{1}$ & 31 & $1.10(0.08)$ & $1.28(0.07)$ \\
\hline Root mass $(\mathrm{g})$ & $0.146(0.011)$ & $0.205(0.011)^{1}$ & 40 & $0.159(0.011)$ & $0.191(0.010)^{1}$ \\
\hline \multicolumn{6}{|l|}{ Whole plant } \\
\hline Total plant mass (g) & $0.461(0.041)$ & $0.691(0.040)^{1}$ & 50 & $0.562(0.043)$ & $0.589(0.038)$ \\
\hline
\end{tabular}

${ }^{1}$ Significant at the 0.05 level between ambient and elevated $\mathrm{CO}_{2}$ means across varieties, and between variety means across $\left[\mathrm{CO}_{2}\right]$.

${ }^{2}$ Increase (\%) of elevated $\left[\mathrm{CO}_{2}\right]$ over ambient $\left[\mathrm{CO}_{2}\right]$. 
develop photosynthetic machinery (leaves) as rapidly growing plants invest heavily in leaves (Tilman 1988; Poorter and Remkes 1990). Allocation priorities switched following the first harvest to increased carbon investment in roots for enhancing water and nutrient uptake.

The absence of variety-specific responses to $\mathrm{CO}_{2}$ enrichment in this investigation, despite differences such as greater rootdepth to root-mass ratios for torreyana than for glandulosa at the Day 8 harvest, is consistent with a previous experiment evaluating genotype-specific growth responses of $P$. glandulosa var. glandulosa seedlings grown from seeds collected along an east-west precipitation gradient $(36-93 \mathrm{~cm} \mathrm{MAP})$ in Texas (Derner et al. 2004). These results contradict literature supporting variety- or genotype-specific responses to $\mathrm{CO}_{2}$ enrichment for other $\mathrm{C}_{3}$ species, including grasses (Goverde et al. 2002; Roumet et al. 1999, 2002), forbs (Andalo et al. 2001), and shrubs (Atkin et al. 1999). Although this leguminous shrub does not conform to responses exhibited by other $\mathrm{C}_{3}$ plants, it is unclear whether this inconsistency results from inherent species characteristics, such as the ability to fix nitrogen, or from soil nutrient and water differences between investigations. For example, $\mathrm{CO}_{2}$ enrichment increased growth more in tree seedlings of xeric than of mesic habitats when soils were dry, but when soils were wet, growth of seedlings from mesic habitats was greater (Catovsky and Bazzaz 1999). Conversely, similar growth responses to $\mathrm{CO}_{2}$ enrichment irrespective of whether soil water was limiting or abundant have been shown in $\mathrm{C}_{3}$ and $\mathrm{C}_{4}$ crop monocultures in a field setting (Derner et al. 2003), and in $C_{4}$ grass seedlings in a glasshouse experiment (Derner et al. 2001).

Substantial $\mathrm{CO}_{2}$-induced growth increases in above- and belowground variables of Prosopis seedlings are in agreement with previous investigations with honey mesquite (Polley et al. 1994, 1996, 1999), Pinus spp. (Jach and Ceulemans 1999; Runion et al. 1999), and other woody species (Cornelissen et al. 1999). Both the absolute and relative responses of aboveground, belowground, and total biomass of honey mesquite seedlings to $\mathrm{CO}_{2}$ enrichment increased from the first to last harvest date of these seedlings, although the effects of $\mathrm{CO}_{2}$ on growth previously have been shown to diminish over extended time periods (i.e., years) (Idso 1999; Jach and Ceulemans 1999). Observed decreases in RGR with increasing plant size are consistent with previous investigations (Jarvis and Jarvis 1964; Bazzaz et al. 1993; Cornelissen et al. 1998). The RGR for both varieties was similar over the 24-day period, resulting in similar total biomass in spite of significantly greater RGR for glandulosa at the Day 8 harvest. Lack of a significant RGR response by Day 24 indicates that the torreyana variety compensated for lower RGR at Day 8. This compensation occurred due to greater increases in aboveground growth in torreyana from Day 16 to Day 24. These increases overshadowed the increasing greater root mass in glandulosa relative to torreyana throughout the 24-day sample period.

A main effect of $\mathrm{CO}_{2}$ enrichment on plant growth is increased ontogeny (e.g., Centritto et al. 1999), which is likely responsible for the rapid response to $\mathrm{CO}_{2}$ enrichment displayed by honey mesquite in this investigation. For example, roots extended $13 \%$ deeper with $\mathrm{CO}_{2}$ enrichment 8 days following emergence. Ecological implications of this greater root depth include access to greater soil water and nutrient supplies, which combined with the marked $\mathrm{CO}_{2}$-induced aboveground responses after 8 days, appears to confer a competitive advantage to honey mesquite seedlings regarding successful establishment, assuming that $\mathrm{C}_{3}$ or $\mathrm{C}_{4}$ grass seedlings do not respond as vigorously to $\mathrm{CO}_{2}$ enrichment. Thus, we should expect that this species will continue aggressive encroachment into grasslands in future $\mathrm{CO}_{2}$-enriched environments, because $\mathrm{C}_{4}$ grasses that currently dominate these grasslands are not as responsive to elevated $\mathrm{CO}_{2}$ as is honey mesquite (Polley et al. 1994).

\section{ACKNOWLEDGMENTS}

Authors wish to thank Alicia Naranjo, Kyle Tiner, Holly Harland, Brooke Kramer, Jenny Fikes, and Dustin Coufal for data collection and entry. Chris Kolodziejczyk maintained $\mathrm{CO}_{2}$ and environmental control systems and data records.

\section{LITERATURE CITED}

Andalo, C., I. Goldringer, and B. Godelle. 2001. Inter- and intragenotypic competition under elevated carbon dioxide in Arabidopsis thaliana. Ecology 82:157-164.

Ansley, J. R., X. B. Wu, and B. A. KRAmp. 2001. Observation: long-term increases in mesquite canopy cover in a north Texas savanna. Journal of Range Management 54:171-176.

ARCHER, S. 1989. Have southern Texas savannas been converted to woodlands in recent history? American Naturalist 134:545-561.

ARCHER, S. 1990. Development and stability of grass/woody mosaics in a subtropical savanna parkland, Texas, U.S.A. Journal of Biogeography 17:453-462.

ARCHER, S. 1995. Tree-grass dynamics in a Prosopis-thornscrub savanna parkland: reconstructing the past and predicting the future. Ecoscience 2:83-99.

Atkin, O. K., M. Schortemeyer, N. McFarlane, and J. R. Evans. 1999. The response of fast- and slow-growing Acacia species to elevated atmospheric $\mathrm{CO}_{2}$ : an analysis of the underlying components of relative growth rate. Oecologia 120:544-554.

Bazzaz, F. A., S. L. Miao, and P. M. Wayne. 1993. $\mathrm{CO}_{2}$-induced growth enhancements of co-occurring tree species decline at different rates. Oecologia 96:478-482.

Bond, W. J., AND G. F. Midgley. 2000. A proposed $\mathrm{CO}_{2}$-controlled mechanism of woody plant invasion in grasslands and savannas. Global Change Biology 6:865869.

Bouma, T. J., K. L. Nielsen, and B. Koutstall. 2000. Sample preparation and scanning protocol for computerized analysis of root length and diameter. Plant and Soil 218:185-196.

BuncE, J. A. 1997. Variation in growth stimulation by elevated carbon dioxide in seedlings of some $\mathrm{C}_{3}$ crop and weeds species. Global Change Biology 3:61-66.

Burkhart, A. 1976. A monograph of the genus Prosopis. Journal of Arnold Arboretum 57:450-525.

Catovsky, S., and F. A. Bazzaz. 1999. Elevated $\mathrm{CO}_{2}$ influences the response of two birch species to soil moisture: implications for forest community structure. Global Change Biology 5:507-518.

Centritto, M., H. S. J. Lee, and P. G. Jarvis. 1999. Increased growth in elevated $\left[\mathrm{CO}_{2}\right]$ : an early, short-term response? Global Change Biology 5:623-633.

ChapIN, F. S. 1980. The mineral nutrition of wild plants. Annual Review of Ecology and Systematics 11:233-260.

Cornelissen, J. H. C., A. L. Carnelli, and T. V. Callaghan. 1999. Generalities in the growth, allocation and leaf quality responses to elevated $\mathrm{CO}_{2}$ in eight woody species. New Phytologist 141:401-409.

Cornelissen, J. H. C., P. Castro-Diez, and A. L. Carnelli. 1998. Variation in relative growth rate among woody species, In: H. Lambers, H. Poorter, M. M. I. van Vuuren [eds.]. Inherent variation of plant growth: physiological mechanisms and ecological consequences. Leiden,The Netherlands: Backhuys Publishers. p 363-392.

Derner, J. D., H. B. Johnson, B. A. Kimball, P. J. Pinter, JR, H. W. Polley, C. R. 
Tischler, T. W. Boutton, R. L. Lamorte, G. W. Wall, N. R. Adam, S. W. Leavitt, M. J. OtTman, A. D. MatTHias, AND T. J. BRooks. 2003. Above- and below-ground responses of $\mathrm{C}_{3}-\mathrm{C}_{4}$ species mixtures to elevated $\mathrm{CO}_{2}$ and soil water availability. Global Change Biology 9:452-460.

Derner, J. D., H. W. Polley, H. B. Johnson, and C. R. Tischler. 2001. Root system response of $\mathrm{C}_{4}$ grass seedlings to $\mathrm{CO}_{2}$ and soil water. Plant and Soil 231 97-104.

Derner, J. D., C. R. Tischler, H. W. Polley, and H. B. Johnson. 2004. Effects of elevated $\mathrm{CO}_{2}$ on growth responses of honey mesquite (Prosopis glandulosa var. glandulosa) seedlings from sites along a precipitation gradient. In: A. L. Hild, N. L. Shaw, S. E. Meyer, E. W. Schupp, and T. Booth [eds.]. Proceedings-Seed and soil dynamics in shrubland ecosystems. Proceedings RMRS-P-31.0gden, UT: U.S. Department of Agriculture, Forest Service, Rocky Mountain Research Station. p 156-160.

HiLu, Y. W., S. Boyd, And P. Felker. 1982. Morphological diversity and taxonomy of California mesquites (Prosopis, Lepminosae). Madrono 29:237-254.

Hoagland, D. R., AND D. I. ARnON. 1950. The water-culture method for growing plants without soil. California Agricultural Experiment Station Circular 347. 39 p.

Huckabee, J. W., Jr., D. R. Thompson, J. C. Wyrick, and E. G. Paulat. 1977. Soil Survey Bell County Texas. Washington, D.C.: USDA Soil Conservation Service, 77 p.

Goverde, M., J. A. Arnone III, and A. Erhardt. 2002. Species-specific reactions to elevated $\mathrm{CO}_{2}$ and nutrient availability in four grass species. Basic and Applied Ecology 3:221-227.

IDSO, S. B. 1999. The long-term response of trees to atmospheric $\mathrm{CO}_{2}$ enrichment. Global Change Biology 5:493-495.

Jach, M. E., and R. Ceulemans. 1999. Effects of elevated atmospheric $\mathrm{CO}_{2}$ on phenology, growth and crown structure of Scots pine (Pinus sylvestris) seedlings after two years of exposure in the field. Tree Physiology 19: 289-300.

Jarvis, P. G., And M. S. Jarvis. 1964. Growth rates of woody plants. Physiologia Plantarum 17:654-666.

Joel, G., F. S. Chapin III, N. R. Chiariello, S. S. Thayer, and C. B Field. 2001. Species-specific responses of plant communities to altered carbon and nutrient availability. Global Change Biology 7:435-450.

Lambers, H., and H. Poorter. 1992. Inherent variation in growth rate between higher plants: a search for physiological causes and ecological consequences. Advances in Ecological Research 23:187-261.

Pennington, R. E., C. R. Tischler, H. B. Johnson, and H. W. Polley. 1999. Genetic variation for carbon isotope composition in honey mesquite (Prosopis glandulosa). Tree Physiology 19:583-589.

Polley, H. W. 1997. Invited synthesis paper: implications of rising atmospheric carbon dioxide concentration for rangelands. Journal of Range Management 50:562-577.
Polley, H. W., H. B. Johnson, and H. S. Mayeux. 1994. Increasing $\mathrm{CO}_{2}$ : comparative responses of the $\mathrm{C}_{4}$ grass Schizachyrium and grassland invader Prosopis. Ecology 75:976-988.

Polley, H. W., H. B. Johnson, H. S. Mayeux, C. R. Tischler, and D. A. Brown. 1996. Carbon dioxide enrichment improves growth, water relations and survival of droughted honey mesquite (Prosopis glandulosa) seedlings. Tree Physiology 16:817-823.

Polley, H. W., H. B. Johnson, and C. R. Tischler. 2002a. Woody invasion of grasslands: evidence that $\mathrm{CO}_{2}$ enrichment indirectly promotes establishment of Prosopis glandulosa. Plant Ecology 164:85-94.

Polley, H. W., H. S. Mayeux, H. B. Johnson, and C. R. Tischler. 1997. Viewpoint: atmospheric $\mathrm{CO}_{2}$ soil water, and shrub/grass ratios on rangelands. Journal of Range Management 50:278-284.

Polley, H. W., C. R. Tischler, H. B. Johnson, and J. D. Derner. 2002b. Growth rate and survivorship of drought: $\mathrm{CO}_{2}$ effects on the presumed tradeoff in seedlings of five woody legumes. Tree Physiology 22:383-391.

Polley, H. W., C. R. Tischler, H. B. Johnson, and R. E. Pennington. 1999. Growth, water relations, and survival of drought-exposed seedlings from six maternal families of honey mesquite (Prosopis glandulosa): responses to $\mathrm{CO}_{2}$ enrichment. Tree Physiology 19:359-366.

PoORTER, H. 1993. Interspecific variation in the growth response of plants to an elevated ambient $\mathrm{CO}_{2}$ concentration. Vegetatio 104/105:77-97.

Poorter, H., AND C. Remkes. 1990. Leaf area ratio and net assimilation rate of 24 wild species differing in relative growth rate. Oecologia 83:553-559.

Roumet, C., G. Laurent, G. Canivenc, and J. Roy. 2002. Genotypic variation in the response of two perennial grass species to elevated carbon dioxide. Oecologia 133:342-348.

Roumet, C., G. LAuRnet, AND J. Roy. 1999. Leaf structure and chemical composition as affected by elevated $\mathrm{CO}_{2}$ : genotypic responses of two perennial grasses. New Phytologist 143:73-81.

Runion, G. B., J. A. Entry, S. A. Prior, R. J. Mitchell, and H. H. Rogers. 1999. Tissue chemistry and carbon allocation in seedlings of Pinus palustris subjected to elevated atmospheric $\mathrm{CO}_{2}$ and water stress. Tree Physiology 19: 329-335.

SAS INSTITUTE, Inc. 1997. SAS/STAT Software: Changes and enhancements through Release 6. 12. Cary, NC: SAS Institute, Inc. 1176 p.

TILmAN, D. 1988. Plant strategies and the dynamics and structure of plant communities. Princeton, NJ: Princeton University Press. 376 p.

Van Auken, 0.W. 2000. Shrub invasions of North American semiarid grasslands. Annual Review of Ecology and Systematics 31:197-215.

Villar, R., E. J. VenekLaAs, P. Jordano, and H. Lambers. 1998. Relative growth rate and biomass allocation in 20 Aegilops (Poaceae) species. New Phytologist 140:425-437. 